\title{
Development of SAVI (Somatic Auditory Visual and Intellectual) Learning Model with Audiovisual to Increase Writing Skill of Elementary Student
}

\author{
${ }^{a}$ Hartati, ${ }^{b}$ Nugraheti Sismulyasih \\ Primary School Teacher Education Department \\ Semarang State University \\ Semarang, Indonesia \\ Corresponding e-mail: hartati@mail.unnes.ac.id ${ }^{\mathrm{a}}$, nugrahetisabilillah@mail.unnes.ac.id ${ }^{\mathrm{b}}$
}

\begin{abstract}
This research aims to (1) produce SAVI learning model that was effective in improving narrative writing skills of Elementary School students (2) to test the effectiveness of the SAVI learning model in improving narrative writing skills. The research method used Research and Development. This research technique used (a) survey, (b) Delphi, (c) classroom action research and (d) experiments. The subject of this research is the fifth grade students in Semarang City. This research sample used "Randomized Group Assignment". The results of this study indicate that the effective SAVI learning model has the following procedures: (a) Preparatory stage: preparing learners for learning, conveying apperception, conveying goals, and explaining learning steps to be undertaken. (b) Delivery stage: the teacher helps the student to find new material. (c) Training stage: guide students to determine themes and keywords from audiovisual observations, guide students developing keywords into sentences and paragraphs, incorporating paragraphs into whole essays. (d) Final stage: giving reinforcement, summarizing learning materials, and reflection. By controlled the intelligence variables and initial knowledge of SAVI learning model assisted audiovisual media was more effective than the conventional learning model in improving the writing skills of fifth grade, where $\mathrm{F}_{\text {count }}\left(\mathrm{F}_{\mathrm{o}}\right)$ $=4,473$ and $\left(F_{p}\right)=0.006$.
\end{abstract}

Keywords: SAVI, audiovisual, narration, elementary school

\section{INTRODUCTION}

Writing skills was a language skill used by a person to communicate to others indirectly by writing. Writing according to Tarigan (1986: 15) could be interpreted as an activity to pour ideas / ideas by using written language as a medium conveyor. According to Gould and Smith (1989: 18) writing was a creative act, the act of writing was creative because required to interpret or made sense of something a experience, a text, an event. Writing was a creative behavior because it required attention or feeling something: an experience or writing event. According to $\mathrm{KBBI}$, the notion of writing was the basic of thoughts or feelings (such as composing, making letters) with writing. Writing meant pouring the writer's heart into writing, so that the author's heart intention could be known to many people through written writing. The ability of a person to pour his or her heart into a writing was very different, influenced by the author's background. So, the quality or quality of each writer's writing was different from each other. However, one important thing that was related to writing activity, an author should pay attention to the capabilities and need of readers.

In line with that Rusyana (1978: 1) states that writing was a form of explanation in arranged by using language. At school called essays. So, essay was the composition of language used as a means of expressing our thoughts, feelings, fantasies, beliefs, and experiences. Writing activities were very important for students because they could train critical thinking students to convey ideas, information, feelings, or just tell something about something that happened to others in the form of writing. Concluding some of the above opinions that writing was a communication activity or interaction with written language with the aim of expressing thoughts, feelings, stances, fantasies, wills, beliefs, and experiences with due regard to applicable rules and conventions.

Writing skills were the most recent language skills of students after listening, speaking, and reading skills. Compared to the other three language skills, writing skills were 
harder to master (Iskandarwassid, 2013: 248). Because writing skills couldn't be formed simply, but grow and develop due to the continuous process repeatedly. The more often a student practicing writing then the more skilled the student was writing. A student was said to be skilled at writing, if the student could convey what they wants clearly so that it could be understood by others as to what they intends to did.

Reality in the field most of the students always face problem in writing process. Its' proven when the students can't be able to write a simple text. As Marta (2003) points out in her research findings that among the 40 students, here are only 11 students that can get good score and the other 29 students are unable to write well. As the result the students get bad score in their writing. So they assumed that writing is very difficult to study. It is caused by low prior knowledge in develoving idea, using sentence pattern, appopriate word or confusion in expressing their idea (Nurhana, 2013: 3). And in fact the limitatons learners are doing it writing tasks, necessary to look a different strategy to help learners to improve the writing skill and most of the interactions that students have is written, it creates more opportunities to reinforce learners language skills and they feel more motivated to learn . (Yeison, 2013: 167). Beside them, in fact written discourse practices were limited to 15 -minute written production exercises, with neither previous planning nor later elaboration, and without any self- or peer evaluation and (Anna Fterniati, 2013:54).

Based on preliminary observations by the researcher when guided the PPL student, as well as reflections made by the teacher, the problem was possible because the method used by teachers was monotone, only lectured and assignments, the media have not utilized maximum by teacher, and the theme given was far from the students environment. Some teachers carried out writing lessons did not emphasize the process of how to write correctly, but only on the results of writing. More students were instructed to write on the topic given by the teacher. In addition, teachers also did not use the appropriate learning model.

Some of the problems above have an impact on the low skills of students in writing essays. The problem was supported by the final semester test result of the fourth grade students in first semester of the academic year 2015/2016 of Gisikdrono Elementary School of Semarang City showed that the writing skill of students was still low. Most students did not reached the KKM that was 65 . From 36 students, there were 23 students did not reach the 65 score.

By looking at the problem it was necessary to take action to improve student writing skill essay. The action was change in learning model that could increase student interest and motivation for optimal learning outcomes. So it was not just a conventional model that was constant but rather the necessity of choosing the right learning strategy including relation to the innovative and fun model. One innovative learning model that could facilitate students with different learning styles was the Somatic Auditory Visualization Intellectually (SAVI) model.

SAVI was a learning activity that combined physical movement, intellectual activity, and the used of all the senses to greatly affect learning (Meier, 2013: 91). The learning process couldn't take optimally without combining the SAVI elements of physical movement, intellectual activity, and the use of all the senses that could affect learning.

SAVI approach is effective for use. This is evidenced by the research of Mujiyem (2011: 364) through SAVI aproach students more active in working on individual tasks. Students are also more willing to ask the teacher, because it is supported by a relaxed learning atmosphere. And the second research that support about SAVI, say that this approach combines physical movements, senses of hearing and sight, as well as intellectual activities in one learning situation. SAVI trains students to interact with their friends, informants, and environment in order to obtain a variety of information. The information collected will later be utilized as the materials used in discussions. In this case, students are placed as the center of attention in instructional process as what the constructivist paradigm explains. The students construct their knowledge based on their own experience to formulate the best solution (Eni, 2013: 446).

Looking at the effectiveness of SAVI, the researchers developed a SAVI model that consisting of somatic, auditory, visual, and intellectual elements in learning to write narrative.

The four elements of SAVI are 1) somatic (learning by moving and do). Somatic degree was to learn while with the sense of touch, kinesthetic, practical, which involves the 
physical by moving the body. 2) Auditory (learning by speaking and listening). Auditory thoughts could continue to capture and store information unwittingly. 3) Visual (learning by observing and describing). Sharpness to process visual information in the brain has a higher portion many compared to other senses. Students who have a tendency to learn visual, will more easily process the information if they could observe what was being discussed someone. 4) Intellectual (learning by solving problems and contemplating). Intellectual was the internal mind of students in using intelligence to reflect on an experience and create relationships, meanings, plans, and values from being learned. Learning with intellectuals was not a trivial way of compartmentalizing emotions, rationality, and academics. Teachers could create learning that enables students to implement the intellectual side in various ways by inviting students to solve problems, formulate questions, and apply new ideas to the task at hand.

A learning process was optimal if all four SAVI elements were present in one whole learning event. Students could learn by watching (V), but they could learn more if they could do something while the learning process was in progress (S), talked about something being learned (A), and thought about how to apply the learned information to complete the task (I).

In effective learning to support the interaction and activities of students in order to achieve meaningfulness in learning, optimum use of various media and learning resources was needed to support positive interaction of students with learning materials so that students could learn through their own way to build their understanding of the concepts studied. Therefore the SAVI learning model applied to improve the quality of the process and the result of learning to write essay writing of elementary students in this study combined with the utilization of audiovisual.

As Singh(2005) defines Audio visual is any device which by sight and sound increase the individual s'experience. Audio Visual Media includes: News Bulletins, Chat shows, Movies, Speeches, Documentaries (Sownthrya, 2014: 385).

The effectiveness of audio visual are to make teaching learning process effective, the respondents viewed that audio visual aids provide knowledge in depth and detail, brings change in class room environment and motivates to teachers and students. (Saima, 2011: 78). Beside them, the impact of use of audiovisual resources on teaching and learning rests on the fact that they stimulate interest and improve learning (Elijah, 2014: 200). Agreeing with this, Dike (1989) opined that audiovisual resources do not only increase the motivation of the teachers and learners, they add clarity to the topic taught and make learning more interesting.

The usefulness of audio visual media is also supported by the results of research of Joni ( 2014: 142) say that student learning outcomes increased after teachers used audio visual media on Science subjects at SMP Negeri 1 Pacitan. And also supported by the research of Saima (2011:78) the mean score more than 3.00 (norm) means that most of the teachers agreed that use of audio visual aids are more effective in teaching process and mean score more than 3.00 (norm) means that most of the students agreed that use of audio visual aids are more effective in learning process at university level. So through the help of audiovisual media, students were expected to be more motivated to always learn.

Based on the above description, then the problem of this research are (1) how was the SAVI learning model with audiovisual media that effective to improve narrative writing skills of elementary school students. (2) to know effectiveness of SAVI learning model with audiovisual media could improve the students narrative writing skill for students. (3) to know the effectiveness of SAVI learning model with audiovisual media increase student activity in narrative writing lesson.

According to the formulation of the problems, the objectives of this research were: (1) to produce SAVI learning model with audiovisual media that effective to improve narrative writing skills of elementary school students (2) to test the effectiveness of SAVI learning model with audiovisual media in improving the learning outcomes of writing narration for elementary school students (3) to test the effectiveness of SAVI learning model with audiovisual media in improving student activity in learning of narrative writing.

\section{METHODS}

This research used Research and Development research design. According to Borg and Gall (1989: 624), Educational 
Research and Development (R \& D) was a process used to develop and validate educational products. The steps in the Research and Development research began with model testing through classroom action research to develop prototype of Somatic Auditory Visualization Intellectually (SAVI) learning model with audiovisual media, followed by model validation test through experiment, until the result of development was ready Disseminated. The research techniques used were: (1) survey, (2) Delphi, (3) classroom action research, and (4) experiment. The research development procedure consisted of four stages: 1) planning stage, 2) model development stage, 3) validation model test stage, and 4) report preparation stage and report distribution.

The location of this research was Gisikdrono 03 Elementary School of Semarang city and Gisikdrono 01 Elementary School of Semarang city. Determination of research sample, used group randomization technique assignment or "Randomized Group Assignment". The subjects of this study were three groups, first group was A fourth grade students of Gisikdrono 01 Elementary School, Semarang city in the academic year 20142015 as a pilot group of SAVI learning model with audiovisual media, second group was B fourth grade students of Gisikdrono 03 Elementary School as a control group, and A fourth grade students of Gisikdrono 03 Elementary School with 36 students as experimental group. The variables of this research were: 1) Somatic Auditory Visualization Intellectually (SAVI) learning model, 2) student activity in learning, and 4) result of learning Indonesian, in the narrative writing skill.

Data collection techniques used: (1) questionnaire, (2) interview, documentation study, (4) observation, (6) test, (7) standard progressive matric test made by Raven. Data analysis techniques used (1) Delphi technique, (2) Descriptive analysis, (3) Test analysis of mean difference (t-test), (4) Qualitative analysis, (5) Covariance analysis.

\section{RESULT AND DISCUSSION}

SAVI learning model with audiovisual media that effective improves the narrative writing skills for elementary school student has the following characteristics: (1) has the main learning step: a) Preparatory stage, the purpose of preparation stage was to generate interest learners, gave them positive feelings about future learning experiences, and put them in optimal situations for learning; b) Delivery stage, aimed at helping learners found learning materials in the form of techniques and how to write narrative interesting, fun, relevant, involving the five senses, and suitable for all learning styles and shared interesting experiences about audiovisual themes to a round buddy; c) The training stage, aimed at helping the scholar align and absorb new knowledge and skills by writing a story based on the experience of audiovisual audiences being aired. d) The performance stage of the outcome, aimed at helping students apply and extend their new knowledge or skills, so that learning outcomes were kept in mind and were increase. (2) the existence of a social system with the characteristics of the proximity of teachers with students rarely lecture, problem investigation exercises, doing collaborative tasks in the group was very dominant in the learning program. 3) the existence of teacher activities, built motivation for mutual learning from fellow students, and the collaborative climate of open and multi-directional, intimate, and democratic teaching-learning interaction, (4) supported facilities in the form of student work sheets, teaching materials, and audiovisual.

A total of $93.33 \%$ of students who are subjected to conventional learning models have learning outcomes in good category, it meant students who were subjected to conventional learning models have mastery of the learning outcomes of narrative writing around $62.5-81.24 \%$. While some $91.11 \%$ of students were subjected to SAVI learning model with audiovisual media have very good learning outcomes, it meant students who were subjected to SAVI learning model with audiovisual media have mastery of learning outcomes of narrative writing about 81,25 $100 \%$. The average score of student learning outcomes subjected of SAVI learning model with audiovisual media was 85.7778 , means very good. While the average score of student learning outcomes subjected of conventional learning model was 70.2222, means good. From $\mathrm{t}$-test with $\mathrm{df}=35$ found coefficient $\mathrm{t}$ count 21.511 and $\mathrm{t}$ probability 14.08751 for $\mathrm{p}<0.05$. Using covariance analysis with intelligence cognizance and initial knowledge measured from the value of narrative writing skill, an average score of narrative writing skill was found for the conventional learning model group was 70.2222; and the SAVI learning model group with audiovisual media was 
85.7778. The difference in scores on writing skills of narrative essays was significant at $p$ $<0.05$, with intelligence cognizance and initial knowledge. Since $\mathrm{F}$ arithmetic $\left(\mathrm{F}_{\mathrm{o}}\right)=4.473$ was greater than $\mathrm{F}$ probability $\left(\mathrm{F}_{\mathrm{p}}\right)=0.006$, so the null hypothesis (Ho) was rejected, and the alternative hypothesis (Ha) was accepted. Thus the hypothesis stating that "By controlling the variables of intelligence and initial knowledge, the SAVI learning model with audiovisual media was more effective than the conventional learning model in improving the learning outcomes of writing the narrative on fourth grade elementary school student be accepted. The level of effectiveness of SAVI learning model with audiovisual media in improving learning outcomes of narrative writing in fourth grade students was $36.26 \%$. Because of the difference in mean score of students' learning outcomes between the experimental groups and the control group was significant, both test the mean difference, t-test, and covariance analysis, it could be concluded that SAVI learning model with audiovisual media was more effective than conventional learning model. This condition was possible because: (1) with reference to the characteristics of Somatic Auditory Visualization Intellectually (SAVI) learning model with audiovisual media applied constructivism, collaborative, student centered, and audiovisual-based principles, students actively and creatively think and discuss problem solving, So that students understanding of the material was better, (2) through discussion and cooperation in group, student insight about a concept growth and got enrichment of material, so that student's knowledge was be better.

A total of $95.55 \%$ of students who were subjected of SAVI learning models with audiovisual media have very good learning activities, with indicators covered: (1) watched the audiovisuals, (2) watched the content and finding themes (3) asked questions and questions, (4) issued opinions, (5) listened to discussion and discussion, (6) wrote discussion reports; (7) presented the results of group discussions, (8) interaction within the group, (9) included problemsolving skills, (10) responded to the opinions of others, (11) summarized the results of the discussions, (12) passion in group discussions, (13) groups, (14) respected the opinions of others. The average score of student learning activity that was subjected of SAVI learning model with audiovisual media was 52.2667, meant very good. While the average score of student learning activity of conventional learning model was 39.7778 mean good. From $\mathrm{t}$-test test found coefficient $\mathrm{t}$ count 18,615 and $\mathrm{t}$ probability 11.13675 for $p<0.05$. By using analysis of covariance with intelligence covariate and initial knowledge measured from student learning activity value, found the average score of student activity value for group of conventional learning model was 39.7778 and SAVI learning model with audiovisual media was 52.2667. Differences in the score of the students' learning activity were significant at $\mathrm{p}<0.05$, with the intelligence cognizance and early knowledge. Since $F$ count $\left(F_{o}\right) 1.083$ was greater than $F$ probability $\left(F_{p}\right) 0.378$, the alternative hypothesis states that "By controlling the intelligence and initial knowledge variables, the (SAVI) learning model with audiovisual media was more effective than the conventional model learning in improving student learning activities, be accepted. This condition was possible because by referring to the characteristics of SAVI learning model with audiovisual media applied constructivism, student centered, and collaborative principles, so students became more active.

\section{CONCLUSION}

Based on the above discussion, it can be concluded that Somatic Auditory Visualization Intellectually (SAVI) learning model with audiovisual media effective improves the quality of learning to write narrative of fourth grade students has the following characteristics: (a) has effective steps covering the preparation stage, stage of delivery, stage of training, and stage of delivery of results. (b) The existence of a social system with the characteristics of the proximity of students with teachers, as well as the proximity of students with friends because of peer tutoring when did tasks collaboratively in groups (c) The existence of teacher actions built motivation for mutual learning from fellow students, and collaborative climate open, multi-directional, familiar, and democratic teaching-learning interactions; (d) the existence of supporting facilities in the form of student work sheets, teaching materials, and audiovisuals displayed through the LCD.

In this study also known that a total of $91.11 \%$ of student's subject of SAVI learning model with audiovisual media have very good learning outcomes. The average score of student learning outcomes that were subject of 
SAVI learning model with audiovisual media was 84.5111 meant very good. While the average score of student learning outcomes that were subject of conventional learning model was 72.4667 means good. The difference of learning outcomes score was significant at $\mathrm{p}<0.05$ where $\mathrm{t}$ count $=18.341$ and $\mathrm{t}$ probability $=10.72093$. By controlling the initial intelligence and knowledge variables, the Somatic Auditory Visualization Intellectually (SAVI) learning model with audiovisual media was more effective than the conventional learning model in improving the learning outcomes of fourth grade students in narrative writing skills. Where $F$ count $\left(F_{0}\right)=$ 14.571 and $F$ probability $\left(F_{p}\right)=0.028$. Thus, the Somatic Auditory Visualization Intellectually (SAVI) learning model with audiovisual media was more effective than conventional learning models in improving the learning outcomes of narrative writing. The level of effectiveness from Somatic Auditory Visualization Intellectually (SAVI) with audiovisual media in improving narrative writing learning outcomes of fourth grade students Gisikdrono Elementary School in Semarang city was $36.26 \%$.

Beside that, a total of $95.55 \%$ of students subject to Somatic Auditory Visualization Intellectually (SAVI) learning model with audiovisual media have learning activities in very good categories. The average score of student learning activity that was subjected to Somatic Auditory Visualization Intellectually (SAVI) learning model with audiovisual media was 52,2667, while the average score of student learning activity that were subjected to conventional learning model was 39,7778 meant good category. Differences score of learning activity score was significant at $\mathrm{p}<0.05$, with coefficient $\mathrm{t}_{\text {count }}=18.615$ and $\mathrm{t}_{\text {probability }}=11.13675$. In addition $\mathrm{F}$ count $\left(\mathrm{F}_{\mathrm{o}}\right)=$ 1.083 and $F_{\text {probability }}\left(\mathrm{F}_{\mathrm{p}}\right)=0.378$, significant at $\mathrm{p}<0.05$. So, the SAVI learning model with audiovisual media was more effective than the conventional learning model in improving student learning activities.

\section{REFERENCES}

[1] Anna Fterniati. (2013). Narrative Skills And Genre Based Literacy Pedagogy Teaching Material: The Case Of Greek Upper Elementary School Pupils
One Year After The Implementation Of The Current Teaching Material. The International Journal of Literacies. 19(4): 53-67.

[2] Borg, Wolter R., \& Gall, Meredith Damien, (1989). Educational Research An Introduction. New York, London : Longman

[3] Depdiknas. (2006). Standar Isi Untuk Satuan Pendidikan Dasar dan Menengah. Jakarta: Badan Standar Nasional Pendidikan.

[4] Departemen Pendidikan nasional 2004. Kurikulum Tingkat Satuan Pendidikan: Bidang Studi Bahasa Indonesia. Jakarta : PN Balai Pustaka.

[5] Elijah Ojowu Ode. (2014). Impact Of Audio-Visual (Avs) Resources On Teaching And Learning In Some Selected Private Secondary Schools In Makurdi International Journal of Research In Humanities, Arts And Literature. 2(5): 195-201.

[6] Eni Dewi Kurniawati. (2013). Developing A Model Of Thematic Speaking Learning Materials Using Savi Approach (Somatic, Auditory, Visual, Intellectual) In Senior High School In Sambas Regency, West Kalimantan Province, Indonesia. International Interdisciplinary Research Journal. 3(4): 444-454.

[7] Joni Purwono. (2014). Penggunaan Media AudioVisual Pada Mata Pelajaran Ilmu Pengetahuan Alam Di Sekolah Menengah Pertama Negeri 1 Pacitan. Jurnal Teknologi Pendidikan dan Pembelajaran. 2(2): 127-144.

[8] Joyce, B., \& Weil, M., (1980). Model of teaching. New Jersey : Prentice Hall Inc.

[9] Meier, Dave. (2002). The Accelerated Learning Handbooks: Panduan Kreatif dan Efektif Merancang Program Pendidikan dan Pelatihan. Diterjemahkan oleh Rahmani Astuti. Bandung: Kaifa.

[10] Mujiyem Sapti. (2011). An Experiment Of Mathematics Teaching Using SAVI Approach And Conventional Approach Viewed From The Motivation Of The Students Of Sultan Agung Junior High School In Purworejo. Mathematics Education. 2(2) $357-366$.

[11] Nurhanna Sari Siregar.(2013). Improving Students' Achievement In Writing Narrative Text Through Problem Based Learning. Jurnal Pendidikan. 2(1): $1-15$.

[12] Saima Rasul. (2011). A Study To Analyze The Effectiveness Of Audio Visual Aids In Teaching Learning Process At Uvniversity Level. Social And Behavioral Sciences. 2(1): $78-81$.

[13] Sowntharya. (2014). Audio Visual Media And English Learners. International Journal On Recent And Innovation Trends In Computing And Communication. 2(2): 384-386.

[14] Sulistyaningsih, Eny. (2010). Peningkatan Kemampuan Menulis Narasi dengan Metode Peta Pikiran (Mind Mapping) Pada Siswa Kelas V SD Negeri Karangasem III Surakarta Tahun Pelajaran 2010/2011. Skripsi. Surakarta: Tidak Diterbitkan.

[15] Tarigan, Henry Guntur. (2008). Menulis sebagai Suatu Keterampilan Berbahasa. Bandung: Angkasa

[16] Yeison Edgardo Herrera Ramírez. (2014). Writing Skill Enhancement When Creating Narrative Texts Through The Use Of Collaborative Writing And The Storybird Web 2.0 Tool. Colomb. Appl. Linguist. J. 15(2):166-183. 